\title{
K otázkám objektivity západního zpravodajství na pozadí zobrazování ukrajinské krize
}

\section{On the Issues of Objectivity of Western News Against the Background of Depicting the Ukrainian Crisis}

\author{
Eva Niklesová \\ (Praha, Česká republika)
}

\begin{abstract}
:
The article focuses on the issues related to not objective/objective and balanced information about the so-called Ukrainian crisis in Western media. The attention is paid to the issues related to the information about Ukraine, to the choice of information sources, the impartiality of journalists, the relevance and meaningfulness of thorough analyses of the objectivity of such news content, etc. The criticism of the Western media related to the Ukrainian crisis, is, however, connected with the commercial nature of media's function, with the difficult orientation in the causes and consequences of Ukrainian crisis and the limited possibility of verifying information, and with the fragmentation of the media audience, and so on.
\end{abstract}

\section{Key words:}

Ukrainian crisis; objectivity of news; analysis of the impartiality of news; criticism of mainstream media; news value; public service media 
V souvislosti se zpravodajským informováním o ukrajinské krizi ${ }^{1}$ se vynořila, resp. (znovu)otevřela (a stále je předmětem diskuzí v laickém i odborném diskurzu), řada otázek spojená s rolí a důležitostí médií v současné společnosti. Tyto otázky se - mj. týkají záležitostí v podobě mediální manipulace a propagandy, ne/možnosti relevantní analýzy vyváženosti/objektivity zpravodajských obsahů apod.

\section{Ukrajinská krize a ne/důvěra v objektivitu zpravodajství v tradičních (mainstreamových) médiích}

Zpravodajství o ukrajinské krizi v tradičních médiích, zejména v médiích veřejné služby, je úzce spjato s otázkou míry ne/důvěry $\mathrm{v}$ objektivitu zpravodajství, se stížnostmi laické i odborné veřejnosti na nevyváženost zpravodajství a s následnými reakcemi médií $\mathrm{v}$ podobě podrobných analýz objektivity, nestrannosti a vyváženosti těchto obsahů. ${ }^{2}$ Cíl těchto analýz však většinou spočivá v obhájení výchozího (avšak nekritického) předpokladu, podle něhož mají média plnit primárně informativní funkci, poskytovat údaje, které nejsou záměrně zatíženy subjektivními a jednostrannými názory, a tudíž představovat platformu pro možnost vytvoření si vlastního úsudku. Jinak řečeno, média mají dokázat, že působí „jako objektivní činitel, který fakta, názory a presvědčení ve zpravodajství zprostředkovává, a nikoli cíleně usměrňuje a tvaruje " [REIFOVÁ 2004, 163]. V rozporu s touto premisou je jednak samotná podstata fungování médií, usilujících o zisk a přízeň recipientů, avšak současně i tematická a názorová rozsáhlost informační agendy spojené s ukrajinskou krizí a obtížná dostupnost ověřených informací z předmětných lokalit. $\mathrm{Z}$ pohledu recipienta se tak nejčastěji řeší otázky spojené s informačním ne/straněním Ukrajině, s pro/protiruskými tendencemi v západních médiích, s ne/možností přejímat zprávy z ruských, ukrajinských či jiných médiii, ${ }^{3}$ se způsobem vyjadřování žurnalistů o sledovaných událostech, osobách a jevech apod.

V kontextu mediálních studií se můžeme setkat s názorem, podle kterého právě způsob západoevropského informování o krizi na Ukrajině mohl významně posílit

1 Za jednu $\mathrm{z}$ hlavních příčin událostí souvisejících s ukrajinskou krizí je obecně považováno rozhodnutí prezidenta Viktora Janukovyče z listopadu 2013, v němž se rozhodl pozastavit př́pravy k podepsání takzvané asociační dohody mezi Ukrajinou a Evropskou unií (The Ukraine-European Union Association Agreement). Podpis této dohody představoval naději pro občany Ukrajiny zejména z centrálních a západních regionů, kteří snili o integraci s Evropou, zatímco občané Ukrajiny hlavně z jihu a východu upřednostňovali úzké vztahy s Ruskem [MENON, RUMER 2015, X].

2 Podle Žantovského je „většina kritiky na neobjektivní informování o situaci na Ukrajině a roli Ruska a mezinárodního společenství směrována na adresu tradičních médií, zejména denního tisku a veřejnoprávní České televize " [ŽANTOVSKÝ 2015].

3 Srov. např. analýzu Jüptnera, mediálního analytika NEWTON Media, s názvem Přebírají česká média ruské nebo ukrajinské informace, v níž je mj. uvedeno, že „Na ukrajinské a(nebo) ruské zdroje poukazovala nejčastěji šestice zpravodajských webů v čele s novinky.cz. [...] Více proukrajinské byly 
nedůvěru ve zpravodajství a stát se jakýmsi pomyslným katalyzátorem pro paušální kritiku fungování tradičních (mainstreamových) médií. O tomto jevu hovoří například německý mediální teoretik Krüger, když uvádí, že „to, co na jaře 2014 započalo masivním hněvem na pocitovanou nevyváženost zpravodajství o Ukrajině a na př́liš negativní obraz o Rusku“, dospělo v principiální kritiku, která může být souhrnně označena např́iklad výrazem Lügenpresse (lživý, prolhaný tisk, lžitisk) či jinými ${ }^{4}$ [KRÜGER 2016, 7]. Zároveň jde dle Krügera [KRÜGER 2016, 10] o uvádění chybných informací, zavádějících ilustračních obrázků a neověřených údajů. ${ }^{5}$ Autor dále uvádí, že lidé pracující v německých médiích na svou obhajobu s oblibou uváděli, že kritika nevyváženosti zpravodajství o Ukrajině pochází od tzv. Putinových trollů, Kremlem placených agentů apod. ${ }^{6}$

Pokud nahlédneme do českého prostředí, zabývalo se v březnu 2014 výzkumem důvěry v média Centrum pro výzkum veřejného mínění při Sociologickém ústavu AV ČR. V šetření s názvem Důvěra některým institucím veřejného života $v$ breznu 2014, kterého se zúčastnilo 260 tazatelů, je mj. uvedeno, že „důvěra občanů ČR $k$ rádiím, televizi i tisku od roku 2011 postupně klesala, $v$ aktuálním výzkumu ale nedošlo $v$ porovnání se situací $v$ září $2013 v$ prípadě duvěry $k$ rádiím a $k$ televizi $k$ žádné

dále weby aktualne.cz (54\% ku $28 \%)$ a blesk.cz (58\% ku $30 \%)$. Internetový mainstream (lidovky.cz, idnes.cz, tyden.cz) byl pritom proukrajinský pouze lehce. Více či méně výraznějši převaha informací ruské provenience charakterizovala naopak parlamentnilisty.cz, blogosféru na idnes.cz, metropol.cz a zejména blisty.cz (39\% ku 61\%). [...] Mainstream (HN, MfD) zde opět o něco častěji sahal k ukrajinským zdrojům, kterýžto sklon byl patrnějši také u Práva (57\% ku 29\%), ještě více pak u $E_{15}$ (67\% ku $24 \%$ ) a zejména u deníku Metro. [...] Na opačném pólu stály Lidové noviny, u nichž byla frekvence ruských zdrojů (57\%). [...] Jednoznačně proruské byly co do původu informací i dikce mezi celostátními listy nakonec pouze Haló noviny (59\% ku 16\%)“ [JÜPTNER 2014].

4 Označení Lügenpresse se podle německých jazykovědců v Darmstadtu stalo německým paslovem (resp. neslovem) roku 2014, novotvarem implikujícím negativní konotace, kdy došlo ke „zneužití“ národního jazyka. Slovo Lügenpresse vzniklo již na počátku 2o. století, propagandisticky bylo užíváno $\mathrm{v}$ průběhu první světové války, poté nacisty během druhé světové války $\mathrm{k}$ hanobení nezávislých sdělovacích prostředků. Nově se toto označení objevilo jako transparentní heslo během demonstrací účastníků Pegidy, protiimigračního hnutí Vlastenečtí Evropané proti islamizaci Západu. Za neslovo roku bylo zvoleno zejména s ohledem na předpoklad neznalosti historického kontextu užívání daného výrazu u skandujících demonstrantů [„Lügenpresse“... 2016].

5 Nedůvěra $\mathrm{v}$ tradiční média $\mathrm{v}$ německém prostředí byla samožrejmě pozorována již dříve, srov. např̀. informace o průzkumu Technické univerzity v Dráždanech z roku 2007/2008, podle níž důvěřovalo německým novinár̆ům pouze $35 \%$ dotazovaných [KRÜGER 2016, 22].

6 V této souvislosti dodejme, že podle informací ve zprávě Světová média Rusko očerňují - kromě těch syrských, konstatovali ruští experti se právě Německo podle Ruského institutu strategických výzkumů (RISI) umístilo „na prvním místě žebríčcu v počtu neobjektivně kritických ,materiálü““; Česká republika patři podle institutu „do skupiny tzv. zlých trpaslikü - zemí, které nevytvárejí velký počet materiálů, ale presto většina z nich má negativní obsah. Na jednu neutrální zprávu o Rusku připadá bezmála pět negativních materiálů. Loni se v českých médiích objevilo pouze 80 neutrálních materiálů o Rusku" [Světová... 2015]. 
statisticky významné změně, tisk si dokonce mírně polepšil (nárůst důvěry o 4 procentní body) ${ }^{67}$ Přestože tedy z šetření vyplynulo, že mezi lety 2013 a 2014 nedošlo $\mathrm{k}$ výrazné změně ve vztahu důvěry českých respondentů v média, $\mathrm{z}$ hlediska dlouhodobějšího vývoje pozorujeme tendenci klesající důvěry v média, jak ilustruje následující graf:

Graf 1: Vývoj důvěry médiím, odborům, církvím (v\%)

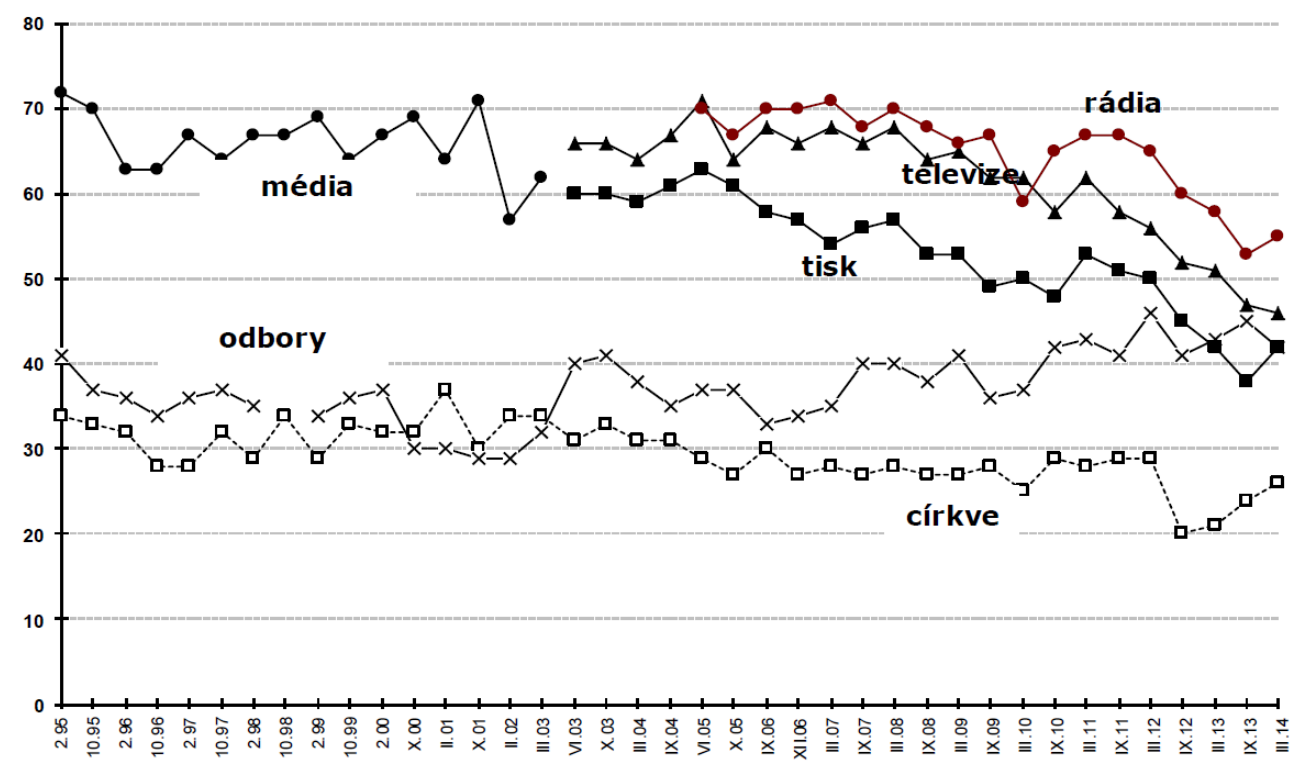

Pozn.: Údaje v grafu predstavují součet odpovědí „rozhodně důvěřuji“ $a$ „spíše důvěřuji“ vyjádřený v procentech. Zdroj: [Důvěra... 2014, 4]

S cílem předložit odborné i laické veřejnosti metodologicky podložené a verifikované závěry o ne/dodržení požadavků na objektivitu a vyváženost vybraných pořadů odvysílaných Českým rozhlasem byla provedena analýza s názvem Mediální reprezentace ukrajinské krize. Analýza objektivity a vyváženosti vybraných pořadu odvysílaných ČRo v období od 1. 1. do 30. 10. 2015, kterou provedla agentura FOCUS Centrum pro sociální a marketingovou analýzu, spol. s r. o. ${ }^{8}$ Tato analýza měla zodpovědět otázku, „zda si Český rozhlas $v$ prípadě reportování o takzvané ukrajinské

7 V šetření je - mj. - dále uvedeno, že v dané době se převažující důvěře těšila „armáda (59\%

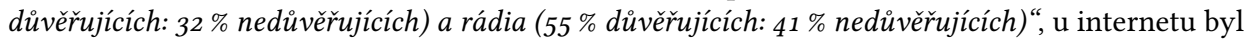
výsledek „42\% důvěřujících: $44 \%$ neduvěrujuících“, u „televize již mírně prevevážil podíl nedůvěrujících (46\% důvěrujících:51 \% nedůvěřujicích)“, u tisku byl zjištěn „výraznějši previs podílu nedůvěrujuicích (42\% di̊věrujících:55\% neduvěrujících)“. Tisková zpráva z tohoto šetření je dostupná online [Důvěra... 2014].

8 Převzato z analýzy, která je dostupná online [Mediální... 2016]. 
krizi během stanoveného období $v$ určených pořadech počínal $v$ souladu s povinnostmi média veřejné služby uvedenými v Zákoně 484/1991 Sb., o Českém rozhlasu a v Kodexu Českého rozhlasu“ [Mediální... 2016, 5]. ${ }^{9} \mathrm{Z}$ výsledků analýzy vyplynulo, „že Český rozhlas prí pokrývání tématu ukrajinské krize ve sledovaném období nepostupoval $v$ rozporu se svými povinnostmi veřejnoprávního média ", upozorněno bylo však na to, že „“̌́ást príspěvkư reprezentujících Rusko vykazuje vůči tomuto subjektu negativní valenci“, že „kvalitativní analýza nalezla ve zkoumaných pořadech dílčí pochybení kmenových žurnalistů ČRo, především se jedná o nejasné zdrojování a kontextualizaci informací" a že „problematickou stránkou analyzovaných pořadu byla identifikace protiruského diskurzu, který má tendenci prostřednictvím zejména nepřsně zdrojovaných informací vytvářet negativní obraz Ruska v kontextu tématu ukrajinské krize“. Zároveň je však konstatováno, že $\mathrm{v}$ žádném $\mathrm{z}$ těchto dílčích problematických okruhů nelze hovořit o narušení objektivity a vyváženosti. ${ }^{10}$

Mohli bychom pokračovat ve výčtu závěrů provedených analýz, v nichž je bud dokazována, nebo naopak zpochybňována objektivita a nestrannost zpravodajství o ukrajinské krizi, avšak problém uchopitelnosti tohoto problému naráží - kromě výše zmíněné podstaty fungování médií, která usilují o zisk a pozornost recipientů - na samotnou podstatu moderních mediálních platforem. Zřejmé snahy médií vypořádat se s kritickými hlasy ohledně ne/vyváženosti zpravodajství o ukrajinské krizi však navzdory použití metodologicky správných a verifikovaných analytických aparátů naráží na úskalí informačního zahlcení současné společnosti, nebot v neustále klokotající záplavě protichůdných informací, názorových proudů, kritických vs. souhlasných reakcí má (modelový) recipient (resp. pravděpodobně již téměř žádný

9 Konkrétně se jednalo o analýzu toho, ,jak stanice ČRo 1 -Radiožurnál a ČRo Plus v období 1. 1 . 2015 až 31. 10. 2015 zpracovaly téma krize na východě Ukrajiny a její ohlasy a dopady“ "[Mediální... 2016, 6], a to na pozadí teorie nastolování agendy s cílem zjistit, „jakým zpưsobem a za užití jakých prostredků či editoriálních postupů Český rozhlas ve sledovaném období pracoval s tématem ukrajinské krize, jakou agendu v rámci svého vysílání nastoloval a s jakými rámci pracoval v prípadě jednotlivých aktérů takzvané ukrajinské krize“ [Mediální... 2016, 8]. Analýza se zaměřovala na sledování míry věnovaného prostoru, na způsob pokrytí tématu, na ne/používání předsudků a uplatňování stereotypizačních mechanizmů ve vztahu k národům a národnostem a jednotlivým stranám konfliktu u kmenových zaměstnanců ČRo, na to, „do jaké míry byl jednotlivým stranám sporu umožněn srovnatelný prístup do vysílání, a to přimou formou zprostredkování jejich jednání nebo formou institucionalizace jejich postojů a názorü " apod.

10 Podrobněji srov. [Mediální... 2016, 86-87]. V českém mediálním prostoru rovněž rezonovaly události spojené se 495stránkovou stížností, která měla být dílem vysokoškolského studenta P. Pražáka a u které bylo toto autorství zpochybňováno a připisováno proruským kruhům v Česku. Tato stížnost skládající se ze 13 kapitol, která obsahovala detailní rozbor zpravodajství o ukrajinské krizi za období od 1. února 2014 do 31. ledna 2016 a v níž bylo doporučeno odvolání generálního ředitele České televize, však byla jak u Rady České televize, tak i u Rady pro rozhlasové a televizní vysílání zamítnuta. K tomuto srov. např. [HORÁK 2017]. Kompletní znění stížnosti je dostupné online [Stížnost... 2017]. 
„běžný občan“) mizivou šanci vyznat se v mediálně-informačním labyrintu a zvážit veškeré dostupné aspekty uchopení událostí spojených s obsáhlou, nejednoznačnou a rozvětvenou problematikou ukrajinské krize, do níž vstupují aspekty př́padné propagandy, trollování a jiné. Za racionální pohled na způsob informování o anexi Krymu by snad bylo možno považovat vyjádření M. Krumla, který se ke kritice tuzemských médií za nevyvážené informování o anexi Krymu ${ }^{11}$ vyjádřil následovně: „Kritici nevyváženosti poněkud zapomínají, že zpravodajství nemá dávat někomu za pravdu a už vůbec ne vybírat zprávy tak, aby bylo dosaženo takzvané názorové objektivity. Skutečnost, že Rusko anektovalo Krym, je nepopiratelná, ani ruská vláda to nezpochybřuje. Odlišný je výklad, proč $k$ tomu došlo. Média tedy maji přinést ve zpravodajství základní stanoviska zúčastněných stran a reakce na ně, všechno ostatní se už odehrává v rámci jiných žánrů - reportáž, analýza, komentář a na ty se vztahují jiná pravidla a jiné požadavky“ [KRUML 2014].

\section{Geografie zpravodajství, zpravodajské hodnoty a ukrajinská krize}

Pohled mediálních teoretiků na způsob podávání zpravodajských informací o ukrajinské krizi se významně dotýká rovněž dalších aspektů: (1) dnes již klasického Lippmannova konceptu zpravodajských hodnot („news value“), definovaným v roce 1922 v knize Public Opinion, za které považoval „jednoznačnost události, prekvapení, prostorovou blizkost, osobní zaujetí a konflikt “ [REIFOVÁ 2004, 7], a (2) s tímto úzce související geografií zpravodajství (news geography, Nachrichtengeographie), oblastí mediálních studií, jež se mj. zabývá popisem (zahraničního) zpravodajství, tím, které státy či světové regiony a $\mathrm{v}$ jaké míře jsou prezentovány. ${ }^{12}$ Na pozadí geografie zpravodajství se míra pravděpodobnosti určité události transformovat se do zprávy proměňuje na základě statusu a blízkosti země, v níž se událost odehrála. U zemí s „vyšším statutem“ a u zemí geograficky bližších je pravděpodobnost přetavení události do zprávy vyšší a naopak [WEBER 2008, 396]. Teorii zpravodajských hodnot, zejména př́mou úměru mezi vysokou mírou mediální atraktivity, prostorovou blízkostí a konfliktem, potvrzují výsledky šetření Postoj české veřejnosti k dění na Ukrajině: říjen 2015 Centra pro výzkum veřejného mínění Sociologického ústavu AV ČR, v němž byl - mj. - zmíněn i aspekt mediální atraktivity dané problematiky [Postoj...

11 Termín anexe Krymu uživá i Ministerstvo zahraničních věcí ČR, a to například v Prohlášení MZV ČR $k$ tzv. „lidovým republikám“: „Plně respektujeme územní celistvost a svrchovanost Ukrajiny. Ruskou anexi Krymu a pokračující prítomnost několika tisíc př́slušníků ozbrojených sil RF na východě Ukrajiny považujeme za hrubé porušení mezinárodního práva a vážné ohrožení míru a stability v Evropě." Zdroj: [Prohlášení... 2017].

12 Ke geografii zpravodajství srov. např. článek Nachrichtengeographie: Beschreibungsmodell und Erklärungsansatz auf dem Prüfstand. Untersuchung am Beispiel der Osteuropaberichterstattung deutscher Tageszeitungen [WEBER 2008]. 
2015]. Z tohoto šetření mj. vyplynulo, že „určité snižení zájmu je pro středně až dlouhodobé konflikty charakteristické - po počáteční aktivizaci zájmu veřejnosti dochází $k$ útlumu mediálního zájmu a k roztažení tématu do dlouhého časového úseku a že stejně jako $v$ jiných prípadech dochází $i$ zde $k$ určitému monotónnímu průběhu (ve smyslu novosti, nikoliv naléhavosti) události, téma postupně překrývají jiné události, atp." Jde o snadno predikovatelné výsledky, které potvrzují, že zejména počátky ukrajinské krize představovaly pro českého diváka recepčně atraktivní obsah, nebot došlo ke koincidenčnímu spojení několika faktorů, zaručujících kýženou mediální atraktivitu: prostorovou blízkost, konfliktnost událostí, vysoký emoční náboj a v neposlední řadě možnost zhlédnutí původního obrazového materiálu, pořízeného českými žurnalisty, a to zejména $\mathrm{v}$ období dlouhodobých občanských nepokojů na kyjevském náměstí Nezávislosti, známých pod názvem Euromajdan.

\section{Závĕr}

Mediální reprezentace událostí spojených s ukrajinskou krizí zasahuje do celé řady rovin, které souvisejí s kredibilitu a objektivitou zpravodajství. Ústřední problém představuje omezená možnost kritického vypořádání se s událostmi kolem ukrajinské krize v západních médiích a s relevancí informací, které nám tato média přinášejí. Tento začarovaný kruh vyústil v kritiku západních mainstreamových médií a v otázku míry př́tomnosti ideologických a politizujících prvků v západním mediálním prostoru.

\section{Literatura:}

Důvěra některým institucím veřejného života v březnu 2014. (2014). Centrum pro výzkum veřejného mínění, Sociologický ústav AV ČR, v. v. i., zpracovala Naděžda Čadová, zveřejněno dne 28. března 2014. <https://cvvm.soc.cas.cz/media/com_form2content/ documents/c2/a1728/f9/po140328.pdf>. [online]. [cit. 12. 4. 2016].

HORÁK,J. (2017): 5oostránková stížnost na ČT nespadla pod stůl, student ji dostal $k$ soudu. Lidovky.cz. <https://www.lidovky.cz/obri-stiznost-projedna-soud-dgp-/ zpravy-domov.aspx?c=A170509_143502_ln_domov_jho>. [online]. [cit. 20. 5. 2017]. JÜPTNER, J. (2014): Přebírají česká média ruské nebo ukrajinské informace? NEWTON media, 18. 8. 2014. <http://www.newtonmedia.cz/cs/mediainfo-cz/analyzy/prebirajiceska-media-ruske-nebo-ukrajinske-informace/detail>. [online]. [cit. 22. 3. 2016]. KRÜGER, U. (2016): Mainstream: Warum wir den Medien nicht mehr trauen. Berlin. KRUML, M. (2014): Češi patři ke světové špičce v hořekování nad médii. MediaGuru. 18. 4. 2014. <https://www.mediaguru.cz/clanky/2014/o4/cesi-patri-ke-svetove-spicce-vhorekovani-nad-medii>. [online]. [cit. 26. 6. 2016]. 
„Lügenpresse“ ist Unwort des fahres. (2016). Spiegel online. 13. 1. 2015. <http://www. spiegel.de/kultur/gesellschaft/luegenpresse-ist-unwort-des-jahres-a-1012678.html>. [online] [cit. 10. 1. 2016].

Mediální reprezentace ukrajinské krize. Analýza objektivity a vyváženosti vybraných pořadů odvysílaných ČRo v období od 1. 1. do 30. 10. 2015. (2016). FOCUS - Centrum pro sociální a marketingovou analýzu. <http://media.rozhlas.cz/_binary/03588583. pdf $>$. [online]. [cit. 29. 5. 2016].

MENON, R., RUMER, E. (2015): Conflict in Ukraine. The Unwinding of the Post-Cold War Order. Cambridge.

Postoj české veřejnosti $k$ dění na Ukrajině: ř́jen 2015. (2015). Centrum pro výzkum veřejného mínění, Sociologický ústav AV ČR, v. v. i. Zpracovali Martin Buchtík a Tomáš Rábek, zveřejněno dne 10. listopadu 2015. <https://cvvm.soc.cas.cz/media/com_ form2content/documents/c2/a1959/f9/pm151110.pdf>. [online]. [cit. 20. 1. 2017].

Prohlášení Ministerstva zahraničních věcí ČR k tzv. „lidovým republikám“. (2017). Ministerstvo zahraničních věcí ČR, 19. 7. 2017. <https://www.mzv.cz/kiev/cz/ zpravy_a_udalosti/http_www_mzv_cz_jnp_cz_udalosti_a_media.html $>$. [online]. [cit. 22. 7. 2017].

REIFOVÁ, I. a kol. (2004): Slovník mediální komunikace. Praha.

Stižnost na zpravodajství České televize k ukrajinské krizi. (1. únor 2014 - 31. leden 2016). (2017). <http://hlidacipes.org/wp-content/uploads/2016/o4/stiznost-na-CT. pdf>. [online]. [cit. 12. 2. 2017].

Světová média Rusko očerňuji - kromě těch syrských, konstatovali ruští experti. (2015). Česká televize. <http://www.ceskatelevize.cz/ct24/svet/1504972-svetovamedia-rusko-ocernuji-krome-tech-syrskych-konstatovali-rusti-experti>. [online]. [cit. 20. 4. 2016].

WEBER, P. (2008): Nachrichtengeographie: Beschreibungsmodell und Erklärungsansatz auf dem Prüfstand. Untersuchung am Beispiel der Osteuropaberichterstattung deutscher Tageszeitungen. MK - Medien und Kommunikationswissenschaft, 56 (3-4), s. 392-413. <http://www.zora.uzh.ch/id/eprint/13176/1/2008_Weber_ Nachrichtengeographie.pdf>. [online]. [cit. 2. 3. 2016].

ŽANTOVSKÝ,P. (2015): Mediální manipulace $v$ digitálním věku. Medias res, 30. 12. 2015. <http://www.mediasres.cz/media-a-pr/2948-petr-zantovsky-medialnimanipulace-v-digitalnim-veku.htm>. [online]. [cit. 12. 1. 2017].

Článek vznikl v rámci řešení grantu č. Do5-45 „Mediální konstrukce vlastenectví ve vybraných ruských médiích"Interního grantového systému Metropolitní univerzity Praha, o. p. s.

\section{O autorce}

Eva Niklesová, Metropolitan University Prague, Department of Media Studies, Prague, Czech Republic, eva.niklesova@mup.cz 